\title{
Feeding habits and their implications for the conservation of the endangered semiaquatic frog Atelognathus patagonicus (Anura, Neobatrachia) in a northwestern Patagonian pond
}

\author{
María Elena Cuello, María Teresa Bello, Marcelo Kun, and Carmen A. Úbeda \\ Centro Regional Universitario Bariloche, Universidad Nacional del Comahue, Quintral 1250, R 8400 FRF San Carlos de \\ Bariloche, Río Negro, Argentina. E-mail: mecuello@bariloche.com.ar.
}

\begin{abstract}
Feeding habits and their implications for the conservation of the endangered semiaquatic frog Atelognathus patagonicus (Anura, Neobatrachia) in a northwestern Patagonian pond. Atelognathus patagonicus (Gallardo, 1962) is an endemic frog species whose distribution is restricted to an endorheic pond system in basaltic basins in the northwest of the Argentinean Patagonia. Atelognathus patagonicus has two morphotypes: aquatic and littoral. This study presents data on the diet of A. patagonicus in Laguna del Burro, in Neuquén Province. Digestive tracts were analyzed for 20 specimens: 17 of the aquatic form and 3 of the littoral form. Diversity and trophic niche breadth, and index of relative importance (IRI) were calculated for the aquatic form. Nine food categories were found in the stomachs and intestine with the most important being Odonate naiads (Rhionaeschna sp.; IRI\% = 86.57) and amphipod crustaceans (Hyalella sp.; IRI\% = 12.89). There was not a statistically significant correlation between snout-vent length and mouth width of the frogs and mean prey lengths. For the littoral form of A. patagonicus, 25 prey categories were found, and all preys were adult terrestrial arthropods. Conclusions about the feeding habits of Atelognathus patagonicus and their implications for the design of conservation programs for the species are also given.
\end{abstract}

Keywords: Anura, Neobatrachia, Atelognathus patagonicus, food habits, conservation, Argentinean Patagonia.

\section{Introduction}

Atelognathus patagonicus (Gallardo, 1962) is an endemic frog whose distribution is restricted to an endorheic pond system formed

Received 2 January 2006.

Accepted 2 August 2006.

Distributed September 2006. by water filtering through basalt basins, located in Neuquén Province, in the northwest of the Argentinean Patagonia ( $38^{\circ} 55^{\prime}$ to $39^{\circ} 08^{\prime} \mathrm{S}$, $70^{\circ} 05^{\prime}$ to $\left.70^{\circ} 30^{\prime} \mathrm{W}\right)$. Its type locality is Laguna Blanca, the main water body in the system, which has a surface area of 1,700 ha and is located within Laguna Blanca National Park. Cei and Roig (1968) have described an "aquatic form" and a "littoral form" of A. patagonicus. 
The "aquatic form" lives in the ponds, associated to underwater rocks, and has welldeveloped cutaneous folds, extensive interdigital membranes and an orange-yellow ventral surface. The "littoral form" is found 70-80 $\mathrm{m}$ away from the water's edge in comparatively dry environments, under volcanic flagstone or in neighboring hydrophilous meadows, and has little-developed cutaneous folds, emarginated interdigital membranes and grayish-white ventral color.

In Argentina, the species is categorized as "In danger of extinction" (Secretaría de Ambiente y Desarrollo Sustentable 2004), upon the suggestion of the Asociación Herpetológica Argentina (Lavilla et al. 2000) due to the disappearance of the main population inhabiting the type locality. Since 1994, Argentinean National Parks Administration lists it as "Autochthonous vertebrate species of special value”, selected for its conservation importance (Administración de Parques Nacionales 1994). On a world level, A. patagonicus has been categorized as Endangered (IUCN et al. 2004).

Atelognathus patagonicus was once the most common amphibian in Laguna Blanca. The seriousness of its decline was noticed in 1984 and towards 1986 all records of this species ceased (Administración de Parques Nacionales 1993). The fact that it has disappeared from the type locality is probably related to the introduction of fishes during the 1940s, 50s and 60s, such as Percichthys colhuapiensis (Percichthyidae), and Oncorhynchus mykiss and Salmo trutta (Salmonidae) (Administración de Parques Nacionales 1993, G. Heredia pers. com.). Today Atelognathus patagonicus is known to inhabit 15 ponds, some of which are transitory (Fox et al. 2005), located inside and outside the National Park. None of these environments originally harbored fish (Cei and Roig 1966, Daciuk 1968).

Various causes have been proposed for the disappearance of amphibians on a worldwide scale, including causes such as habitat destruction and fragmentation, natural fluctuations of population sizes and the introduction of exotic fish (Blaustein and Wake 1995, Hecnar and M’Closkey 1997).

It is currently accepted that in order to design a conservation strategy for a certain species, it is necessary to know about its biology and behavior. The use of food resources is one of the most relevant features of the life history of a species, as it affects survival and regulates future recruitment.

The only information available on A. patagonicus feeding habits is the anecdotic mention in Cei and Roig (1968) which refers only to the “aquatic form”. In order to make a contribution to the understanding of $A$. patagonicus biology and behavior, and aid the identification of factors that may have determined its extinction in Laguna Blanca, this study aims to describe the summer diet of post-metamorphic stages of A. patagonicus in an unaltered neighboring environment (Laguna del Burro and its surroundings), by means of a) a qualitative and quantitative analysis of its components in the "aquatic form”, b) an assessment of the trophic behavior of the species in terrestrial environment ("littoral form") and c) an analysis of the relationship between prey size and frog size.

As A. patagonicus is a protected species, a minimal sample was analyzed. In view of the results, it was not worth conducting a more intensive survey. Although Frost et al. (2006) have included Atelognathus in the redefined family Ceratophryidae, there are unpublished data from Basso, Hillis and Cannatella (in prep.) to support a new alternative arrangement $(\mathrm{N}$. Basso pers. com.).

\section{Materials and Methods}

\section{Study Area}

Laguna del Burro (39 06' S, 70²4' W, $1,378 \mathrm{~m}$ a.s.l.) belongs to a system of endorheic ponds in basalt basins, where the arid climate determines vegetation made up of low, thorny shrubby steppe. The pond has a surface area of 
14 ha, a perimeter of $1.8 \mathrm{~km}$ (Cuello 2002) and a maximum depth of $2 \mathrm{~m}$ (Ortubay et al. 2006). The surface freezes during cold winters, while in summer the surface temperature may reach $23^{\circ} \mathrm{C}$. The shore is rocky in some parts and made up of fine sediment in others. Along a very small part of the shore there are also hydrophilous meadows or "mallines" that extend up to 70-80 m away from the edge of the pond.

The submerged macrophyte Miriophyllum quitense is a major component of the ecosystem of the Laguna del Burro. According to our own unpublished data, the nekton includes adult Heteropteran insects such as notonectids and corixids, and ditiscid and hydrophilid coleopterans; the littoral benthos includes amphipods of the genus Hyalella, hirudineans and insects, mainly distiscid coleopteran larvae and odonate naiads.

We found two terrestrial anurans, Pleurodema bufoninum (Leptodactylidae) and Bufo spinulosus papillosus (Bufonidae) in the vicinity of the pond. In addition, Cei and Roig (1968) described Atelognathus praebasalticus in the area.

\section{Methods}

Twenty clinically healthy A. patagonicus specimens (17 of the "aquatic form" and 3 of the "littoral form" sensu Cei and Roig, 1968) were used for the present study. Fifteen of them, captured in January-March 2001, were obtained from the collection deposited at Centro Regional Bariloche, Universidad Nacional del Comahue. The other five specimens were collected by us in January 2003, and are deposited at the same collection. All specimens were killed with anesthetic overdose, fixed in $10 \%$ formalin directly after capture and preserved in $70 \%$ alcohol.

Individuals were measured and their sex determined. A manual caliper was used (to the nearest $0.1 \mathrm{~mm}$ ) to record snout-vent length (SVL) and mouth width. Sex was determined by direct observation of gonads. The gastrointestinal tract of each individual was dissected from the cardias to the posterior end of the large intestine and its content was classified according to whether items came from the stomach, small intestine or large intestine. A stereoscopic microscope was used for observations.

The taxonomic category of preys was determined to the lowest possible level. The whole or fragmented material present in the stomach and small intestine was used to quantify the preys. When there were partly digested organisms, those with well-preserved key structures were considered for identification. The content of the large intestine was analyzed qualitatively to obtain additional information.

Prey volume was estimated by water displacement $(0.01 \mathrm{ml})$. For very small or incomplete prey items, mean volume was calculated using reference specimens from the same taxon. Frequency of occurrence of each taxon was calculated as number of digestive tubes in which a certain taxon was found, divided by total number of digestive tubes examined.

To analyze the relationships between size of prey and size of predator 1) the data were logtransformed to fit normal distribution, 2) the values of the independent variables SVL and mouth width were plotted against the mean length of all preys found in the frog, and 3) the degree of correlation between these variables was calculated using the Spearman correlation analysis (Conover 1980). Means are given as mean \pm SD.

In order to determine the contribution of each food category to the diet of the "aquatic form" of A. patagonicus, we calculated the index of relative importance (IRI), proposed by Pinkas et al. (1971). To calculate this index, all preys eaten were treated as a single sample. The food categories that made up $20 \%$ or more to the diet composition were considered primary; those that made up $1 \%$ to $19.9 \%$, secondary, and less than $1 \%$, incidental (King 1986).

Trophic diversity $(H)$ of the "aquatic form" was calculated following Hurtubia (1973), who estimates trophic diversity for each predator using Brillouin's (1965) formula: $H=(1 / N)$ 
$\left(\log _{2} N !-\Sigma \log _{2} N_{\mathrm{i}} !\right)$. Prey item data from frogs taken at random were used to calculate the accumulated trophic diversity $\left(H_{k}\right)$ and determine the minimum sample following Pielou's (1966) method, as modified by Hurtubia (1973).

Trophic niche breadth $(B)$ was estimated by applying Levins (1968) index: $B=1 / \sum_{i=1}^{n} p_{i}^{2}$ where $p_{i}$ is the proportion of the item $\mathrm{i}$ (number) in the diet of $A$. patagonicus; $B$ takes values between 1 and $n$, where $n$ is total number of resource states (prey categories). In addition, the standardized Levins index ( $B$ ') becomes independent of the number of resources available and enables an absolutely equivalent comparison between two species (Hurlbert 1978, Krebs 1989). This index was estimated using the formula: $B^{\prime}=B-1 / n-1$. The value of $B^{\prime}$ ranges from 0 to 1 .

\section{Results}

Analysis of the diet of the "aquatic form"

The "aquatic form” specimens (5 males; SVL $34.8 \pm 2.2 \mathrm{~mm}$ and 12 females; SVL $38.5 \pm$ $5.4 \mathrm{~mm}$ ) were grouped into 3 size classes. The 30-35.9 $\mathrm{mm}$ and 36-41.9 mm length intervals comprised $82.4 \%$ of the frogs; larger sizes were less frequent, with only $17.6 \%$ in the $42-47.9$ mm interval (Figure 1).

The diet was made up of aquatic arthropods. Six prey categories were identified in the stomach-small intestine, and another 3 in the large intestine. The categories contributed an equivalent number of adult and larval stages in the stomach-small intestine (Table 1). Mean trophic diversity was $\bar{H}=0.23 \pm 0.29$ and accumulated trophic diversity was $H_{k}=1.33$. The number of specimens in the minimum sample was 15 (Figure 2).

The contribution of each food category to the diet studied, according to IRI, is shown in Table 2. Naiads of Rhionaeschna sp. (Aeshni- dae, Odonata)were identified as the primary food items (IRI \% = 86.57), and amphipods of the genus Hyalella as the secondary food items (IRI \% = 12.89). It is worth noting that Rhionaeschna sp. naiads and Hyalella sp. were present in $76.5 \%$ and $47.1 \%$ of the stomachs-small intestines, respectively (Table 2). The other groups: Dytiscidae and Hydrophilidae (Coleoptera), Coenagrionidae (Odonata), and Chydoridae (Cladocera) were incidental food items. Complementarily, the prey categories found in the large intestine were: Podocopa (Ostracoda), Polyphaga (Coleoptera) and Chironomidae (Diptera) (Table 1). Trophic niche breadth was: $B=2.35 ; B^{\prime}=0.27$.

Prey length ranged from 1.4 to $29.3 \mathrm{~mm}$, with most prey being in the 5 - $9.9 \mathrm{~mm}$ range; preys measuring 15 to $24.9 \mathrm{~mm}$ were the least frequent, and the only preys larger than $20 \mathrm{~mm}$ were Rhionaeschna sp. naiads (Figure 3).

A qualitative connection was found between the size of the frogs and consumption of certain prey species (Figure 4). The diet of smaller frogs was composed mainly of amphipods (small preys), while in larger frogs, amphipods were replaced by large preys, such as Rhionaeschna sp..

Regarding the volume of ingested food, results show that the size of the food taken by almost half the frogs did not exceed $0.2 \mathrm{ml}$, and only $30 \%$ had a volume near $1 \mathrm{ml}$ due to the presence of two or more Rhionaeschna sp. specimens (Figure 5). The mean number of prey per individual frog was $2.2 \pm 1.4$.

The range of ingested prey length for each predator size was wide. There was no statistically significant correlation between frog body size and mean prey length $\left(r_{\mathrm{s}}=0.46, P=0.085\right)$ or between frog mouth width and mean prey length $\left(r_{\mathrm{s}}=0.47, P=0.075\right)$

\section{Analysis of the diet of the "littoral form"}

Three specimens of the "littoral form" were analyzed: 1 male (SVL $22 \mathrm{~mm}$ ) and 2 females (SVL 27, and $33.7 \mathrm{~mm}$ ). Thirty-six preys were found in their gastro-intestinal contents. Twenty 
Table 1 - Organisms making up the diet of the "aquatic" and "littoral” forms (sensu Cei and Roig 1968) of Atelognathus patagonicus at Laguna del Burro (Neuquén, Argentina). Stages: n=naiad; l=larva; a=adult. * aquatic stage; ** land dispersal stage.

\begin{tabular}{|c|c|c|c|c|}
\hline \multirow[b]{2}{*}{ Prey categories } & \multicolumn{2}{|c|}{ "aquatic form" } & \multicolumn{2}{|c|}{ "littoral form" } \\
\hline & $\begin{array}{c}\text { Stomach } \\
+ \text { small } \\
\text { intestine }\end{array}$ & $\begin{array}{c}\text { Large } \\
\text { intestine }\end{array}$ & $\begin{array}{c}\text { Stomach } \\
\text { + small } \\
\text { intestine }\end{array}$ & $\begin{array}{c}\text { Large } \\
\text { intestine }\end{array}$ \\
\hline
\end{tabular}

\section{Aquatic Invertebrates}

Odonata

Aeshnidae Rhioaeschna sp. (n)

Coenagrionidae (n)

Diptera

Coleoptera

Chironomidae (l)

Hydrophilidae Tropisternus sp. (l)

Dytiscidae Lancetes sp. (a) *

Polyphaga (a) Undetermined 1

Amphipoda

Hyalellidae Hyalella sp. (a)

Ostracoda

Podocopa (a)

Cladocera

Chydoridae (a)
$\mathrm{X}$

$\mathrm{X}$

$\mathrm{X}$

$\mathrm{X}$

$\mathrm{X}$

$\mathrm{X}$
$\mathrm{X}$

X

$\mathrm{X}$

$\mathrm{X}$

Terrestrial Invertebrates

Collembola
Psocoptera (a)

Hemiptera

Homoptera

Hymenoptera

Diptera

Coleoptera

Acarina

Araneae

Solifuga (a)
Poduridae (a)

Corixidae (a) **

Aphidiidae (a)

Formicidae Myrmicinae (a)

Formicidae Undetermined 1 (a)

Tephritidae (a)

Dolichopodidae (a)

Lonchopteridae (a)

Tipulidae (a)

Sciaridae (a)

Brachycera (a) Undetermined 1

Brachycera (a) Undetermined 2

Brachycera (a) Undetermined 3

Curculionidae (a)

Carabidae (a)

Polyphaga (a) Undetermined 1

Polyphaga (a) Undetermined 2

Cryptostigmata / Oribatei (a)

Prostigmata (a)

Labidognatha /Araneidae (a)

Labidognatha (a) Undetermined 1

Labidognatha (a) Undetermined 2

Labidognatha (a) Undetermined 3
$\mathrm{X}$

$\mathrm{X}$

$\mathrm{X}$

$\mathrm{X}$

$\mathrm{X}$

$\mathrm{X}$

$\mathrm{X}$

X

$\mathrm{X}$

X

$\mathrm{X}$

$\mathrm{X}$

$\mathrm{X}$

$\mathrm{X}$

X

X

$\mathrm{X}$

X

$\mathrm{X}$

$\mathrm{X}$

$\mathrm{X}$

$\mathrm{X}$

$\mathrm{X}$

X

$\mathrm{X}$ 
Table 2 - Index of relative importance (IRI) and percentage values for number, volume, frequency of ocurrence and IRI of the food categories for Atelognathus patagonicus, “aquatic form” (sensu Cei and Roig 1968) at Laguna del Burro (Neuquén, Argentina).

\begin{tabular}{lccccc}
\hline Food category & \% N & \% V & \% FO & IRI & \% IRI \\
\hline Aeshnidae (Rhionaeschna sp.) & 55.26 & 95.90 & 76.47 & 11559.61 & 86.57 \\
Hyalellidae (Hyalella sp.) & 34.21 & 2.38 & 47.06 & 1721.75 & 12.89 \\
Dytiscidae (Lancetes sp.) & 2.63 & 1.36 & 5.88 & 23.47 & 0.18 \\
Hydrophilidae (Tropisternus sp.) & 2.63 & 0.08 & 5.88 & 15.94 & 0.12 \\
Coenagrionidae & 2.63 & 0.29 & 5.88 & 17.16 & 0.13 \\
Chydoridae & 2.63 & 0.0002 & 5.88 & 15.48 & 0.12 \\
\hline
\end{tabular}

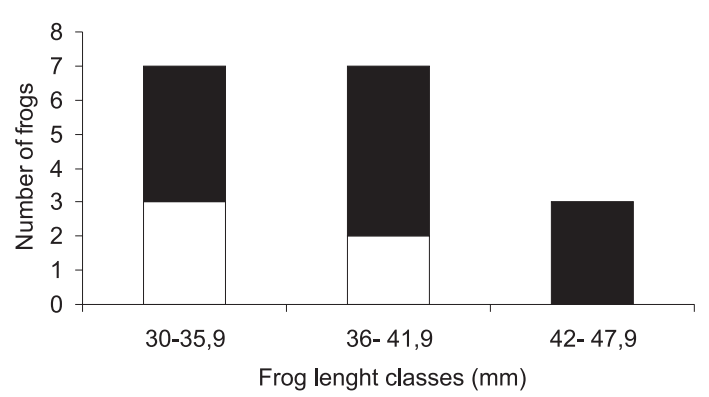

Figure 1 - Number of male and female Atelognathus patagonicus "aquatic form" (sensu Cei and Roig 1968) for three length classes. Laguna del Burro (Neuquén, Argentina). Empty bars $=$ males; filled bars $=$ females.

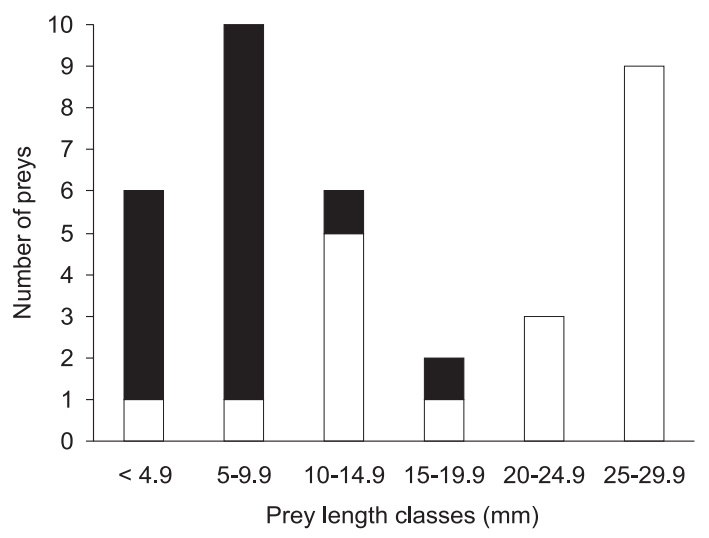

Figure 3 - Distribution according to length classes of total preys ingested $(n=38)$ by Atelognathus patagonicus "aquatic form" (sensu Cei and Roig 1968), Laguna del Burro (Neuquén, Argentina). Empty bars = Rhionaeschna sp.; filled bars $=$ other preys.

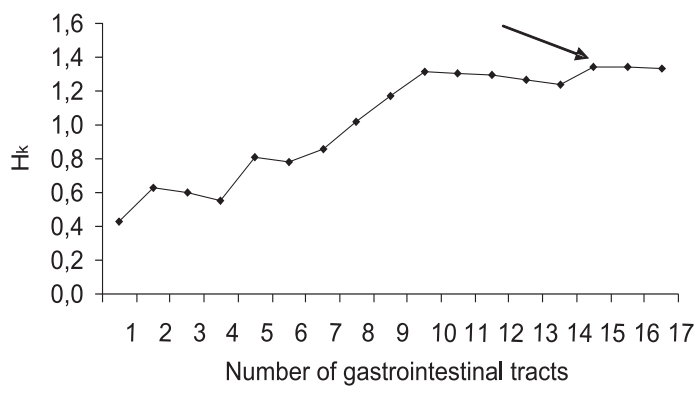

Figure 2 - Accumulated trophic diversity curve $\left(H_{k}\right)$ for Atelognathus patagonicus, "aquatic form” (sensu Cei and Roig 1968). The arrow indicates the approximate point as from which $H_{k}$ tends to become stable, and determines the minimum sample.

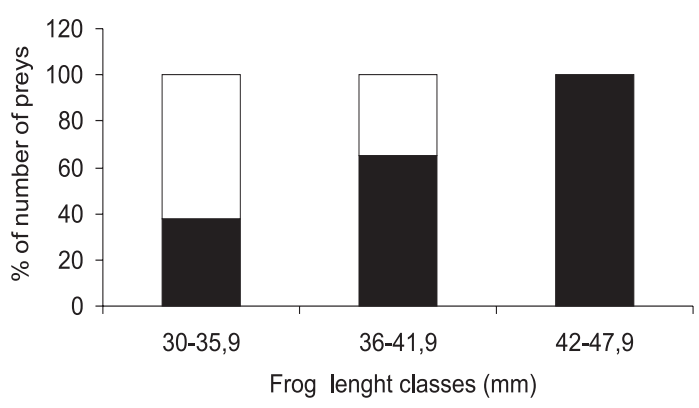

Figure 4 - Distribution of the main preys among frogs belonging to different length classes. Atelognathus patagonicus “aquatic form” (sensu Cei and Roig 1968). Laguna del Burro (Neuquén, Argentina). Empty bars = Rhionaeschna sp.; filled bars = Hyalella $\mathrm{sp}$. 


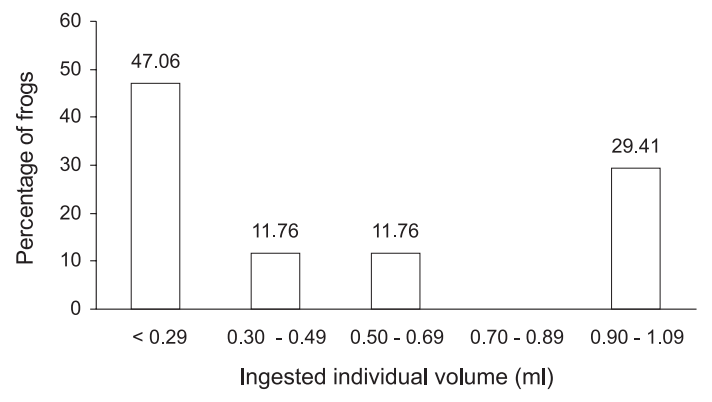

Figure 5 - Distribution of percentages of frogs according to the volume (ml) of preys ingested. Atelognathus patagonicus “aquatic form” (sensu Cei and Roig 1968). Laguna del Burro (Neuquén, Argentina).

categories were recognized in the stomach-small intestine, and five in the large intestine (Table 1). All preys were adult terrestrial arthropods. Dytiscidae had been captured in the land dispersal stage.

The most numerous prey items in the stomach-small intestine were: Diptera $(n=15 ; 48 \%$ of all prey items), among which at least 5 families were recognized, followed by Coleoptera and Araneae (both with $n=4 ; 15 \%$ ). The preys found in the large intestine increased the trophic range of the "littoral form", including Formicidae, Corixidae and Psocoptera, in addition to two unidentified Diptera not found in the first section of the digestive tube. The number of preys for each frog was 20, 12 and 9, respectively.

\section{Discussion}

The diets of the two "forms" of Atelognathus patagonicus, which diverge widely in habitat, were completely different, though both were carnivorous. Each form took preys associated exclusively to their own environment: aquatic or terrestrial.

In the aquatic environment, 15 frog specimens seemed to provide a representative sample (Figure 2). The diet diversity was low and the trophic niche breadth $\left(B=2.35 ; B^{\prime}=0.27\right)$ indicates that its diet is dominated by few prey categories. The versatility of $A$. patagonicus is shown through the analysis of the digestive tracts of the "littoral form", in which, despite the small sample size $(n=3)$, showed that it captures a wide variety of terrestrial preys regarding taxa, sizes and habits.

In the "aquatic form", the high value of IRI for Rhionaeschna naiads was justified by its number, volume and frequency of occurrence. Amphipods were outstanding in number and frequency of occurrence. According to relative importance, capture of other preys was incidental: Chidoridae, for example, is usually found in the stomach content of Rhionaeschna sp. naiads (MK pers. obs.) and may have been secondarily ingested. In their brief comment on what these frogs feed on in ponds belonging to the system, Cei and Roig (1968) cite amphipods, leeches, small arthropods and Nostocaceae algae as the main components of the diet. No plant matter was found to have been ingested in this study.

Among aquatic anurans, we found that Xenopus laevis (Pipidae) has some of the same tendencies as A. patagonicus, such as trophic fidelity to the aquatic environment, and presence of Odonata naiads and amphipods in its diet (Schoonbee et al. 1992, Lobos et al. 1999). In contrast to A. patagonicus, $X$. laevis adapts to a variety of environmental conditions and has a very wide trophic range, including items from plants to tadpoles and fishes, and occasionally some terrestrial invertebrates.

The taxonomic composition of the diet of the A. patagonicus "littoral form" is comparable to that of the terrestrial frog Pleurodema bufoninum (Leptodactylidae), which is found in the same microhabitats. Terrestrial arthropods, in particular ants (Formicidae), beetles (Curculionidae, Carabidae), mites and spiders, were food items that both species were found to have in common (Pincheira-Donoso 2002, Bello et al. 2005).

The morphology, escape response and temporal and spatial availability of the organisms 
eaten by A. patagonicus differ between habitats. Aquatic preys inhabit the underside of rocks or are slow swimmers, while the preys associated to the terrestrial environment are usually weak fliers or epigeous walkers. The possibility of living in aquatic and dry environments, with the consequent diversification of preys, demonstrates the species' plasticity and might explain its presence in temporary ponds. The results showed no relationship between A. patagonicus body and mouth size and prey length. Although the main prey categories and sizes were accessible to all sizes of the "aquatic form", a food shift was noticed to occur in association to the increase in size of the predator involving change in the type of prey: amphipods appear as the dominant prey in smaller frogs, and as the predator size increases, the frogs tend to replace the amphipods by Rhionaeschna sp., a large prey. This fact should be attributed not only to the relationship between $A$. patagonicus and its preys items sizes, but also to a relationship between frog size and its capacity to capture and ingest preys whose vulnerability also changes in relation to predator size (Hyatt 1979, Hirai and Matsui 2002). Nevertheless, it seems that the replacement of amphipods (modal length $=7$ $\mathrm{mm}$ ) by large Rhionaeschna sp. naiads (modal length $=29 \mathrm{~mm}$ ) found in Laguna del Burro should not be extended for other ponds. In Laguna del Hoyo (Laguna Blanca National Park), for example, Hyalella sp., a relatively small prey item, is a primary food item for all frog size classes (Cuello et al., in press).

The overrepresentation of Rhionaeschna sp. and Hyalella sp. in the diet of A. patagonicus agrees with its nutritional value, as the caloric energy contained in Odonata and Crustacea is high: 5149.8 and $3523.7 \mathrm{J.g}^{-1}$ in wet mass, respectively (Cummins and Wuycheck 1971, Penczak et al. 1984). Therefore, it is conceivable that the decline of the dominant organisms in the diet of $A$. patagonicus would cause catastrophic effects on its populations.

The extinction of $A$. patagonicus in Laguna Blanca may have occurred due to the establish- ment of fish in the environment (Administración de Parques Nacionales 1993, Cuello 2002, Fox et al. 2005, Ortubay et al. 2006). Several decades after the introduction of $P$. colhuapiensis, significant changes were reported in the aquatic biota: alteration of plankton and littoral benthos, reduction of macrophytia and decline of aquatic birds populations, along with the disappearance of A. patagonicus (Ortubay et al. 2006).

Percichthys colhuapiensis is a benthivorous amphipod-consuming fish. Studies on the feeding habits of this species in North Patagonian lakes and reservoirs classify it as a voracious carnivore (Ferriz 1989, Cussac et al. 1998, Macchi et al. 1999) that includes in its diet animal organisms from benthos, nekton and macrophytia, and becomes piscivorous with growth and increase in size.

In the light of current knowledge, the following factors may have contributed to the local extinction of the frog in Laguna Blanca after the introduction of fishes: disturbance of their habitat (Ortubay et al. 2006), predation (Cuello and Perotti 2006), susceptibility to disease (Fox et al. 2005) and alteration of their diet. This study provides evidence supporting the idea that might have occurred a trophic niche overlap between native frogs and introduced fishes in Laguna Blanca. Mazzuchelli (1991) found Hyalella sp. to be the dominant item in the diet of juveniles and adults of $P$. colhuapiensis in this lake. It also highlights the need for better information on requirements of native species and on possible interspecific relationships before and after species introductions Meanwhile, in order to prevent possible additional losses, it is recommended that the introduction of fish into environments such as the fish-free endorheic ponds of Patagonia should be severely discouraged.

\section{Acknowledgements}

We would like to thank Domber, S., Hoermann, I., Martínez, O., Pietrobon, M. and Vidoz, 
Q. of Laguna Blanca National Park for supporting our field work, and Hougham, V. for supporting our lab work; Fox, S. and Basso, N. for providing material from the collections under their care ; Bachmann, A. and Muzón, J. for the identification of aquatic arthropods; Macchi, P. for providing bibliography; Baccalá, N., Duré, M., Grigera, D., Kehr, A., Lajmanovich, R., Martori, R., Peltzer, P. and Trejo, A., and three anonymous reviewers for their suggestions on the study and text of the manuscript . This project was partly supported by research grants from Universidad Nacional del Comahue (B 101), Wildlife Society Conservation (Research Fellowship Program) and Rufford Small Grant (for nature conservation) in association with Whitley Laing Foundation. Capture of specimens was authorized by the Government of Neuquén Province, Argentina (Resolution 885).

\section{References}

Administración de Parques Nacionales. 1993. Plan General de Manejo del Parque Nacional Laguna Blanca. Buenos Aires, Argentina. Delegación Técnica Regional Patagónica, Administración de Parques Nacionales. Resolución 65/94. 63 pp.

Administración de Parques Nacionales. 1994. Res. 180/94. Listas de vertebrados de valor especial. Parques Nacionales, Reservas Nacionales y Monumentos Naturales Patagónicos. Buenos Aires, Argentina. Administración de Parques Nacionales. 8 pp. URL: http://www.sib.gov.ar.

Bello, M. T., V. Hougham, C. A. Úbeda, and M. E. Cuello. 2005. Pleurodema bufoninum (NCN). Diet. Herpetological Review 36: 303-304.

Blaustein, A. R. and D. B. Wake. 1995. The puzzle of declining amphibian populations. Scientific American 272: 52-57.

Brillouin, L. 1965. Science and Information Theory. New York. Academic Press. 245 pp.

Cei, J. M. and V. G. Roig. 1966. Los caracteres biocenóticos de las lagunas basálticas del oeste del Neuquén. Boletín de Estudios Geográficos 13: 182-201.

Cei, J. M. and V. G. Roig. 1968. Telmatobiinos de las lagunas basálticas de Neuquén (Anura, Leptodactylidae). Physis 27: 265-284.
Conover, W. J. 1980. Practical Nonparametric Statistics, 2nd edition. New York. John Wiley and Sons Inc. 493 pp.

Cuello, M. E. 2002. Atelognathus patagonicus (Anura, Leptodactylidae): distribución, hábitat, fenología y estado de conservación en el Parque Nacional Laguna Blanca y alrededores. Unpublished Biol. Lic. Thesis. Centro Regional Universitario Bariloche, Universidad Nacional del Comahue, Argentina.

Cuello, M. E. and M. G. Perotti. 2006. Decline of the endemic frog Atelognathus patagonicus from Laguna Blanca, Neuquén, Argentina: assessment of the effect of fish introduction. Froglog, Newsletter of the Declining Amphibian Populations Task Force 73. URL:http://www.open.ac.uk/daptf/froglog/.

Cuello, M. E., C. A. Úbeda, M. T. Bello and M. Kun. Atelognathus patagonicus (NCN). Diet. Herpetological Review, in press.

Cummins, K. W. and J. C. Wuycheck. 1971. Caloric equivalents for investigations in ecological energetics. Internationale Vereinigung für theoretische und angewandte Limnologie, Verhandlungen 18: 1-158.

Cussac, V. E., D. Ruzzante, S. Walde, P. J. Macchi, V. Ojeda, M. F. Alonso, and M. A. Denegri. 1998. Body shape variation of three species of Percichthys in relation coexistence in the Limay River basin, in northern Patagonia. Environmental Biology of Fishes 53: $143-153$.

Daciuk, J. 1968. La fauna del Parque Nacional Laguna Blanca. (Estudio zoo-ecológico preliminar). Anales de Parques Nacionales 11: 225-304.

Ferriz, R. A. 1989. Alimentación de Percichthys colhuapiensis (Mac Donagh, 1955) y P. trucha (Girard, 1854) (Osteichthyes, Percichthyidae) en el embalse Ramos Mexía, provincia del Neuquén, Argentina. Iheringia, Série Zoologia 69: 109-116.

Fox, S. F., J. H. Yoshioka, M. E. Cuello, and C. Úbeda. 2005. Status, distribution, and ecology of an endangered semiaquatic frog (Atelognathus patagonicus) of northwestern Patagonia, Argentina. Copeia 2005: 921929.

Frost, D. R., T. Grant, J. Faivovich, R. H. Bain, A. Haas, C. F. B. Haddad, R. O. de Sá, A. Channing, M. Wilkinson, S. C. Donnellan, C. J. Raxworthy, J. A. Campbell, B. L. Blotto, P. Moler, R. C. Drewes, R. A. Nussbaum, J. D. Lynch, D. M. Green and W. C. Wheeler. 2006. The amphibian tree of life. Bulletin of the American Museum of Natural History 297: 1-370.

Hecnar, S. J. and R. T. M'Closkey. 1997. The effects of predatory fish on amphibian species richness and distribution. Biological Conservation 79: 123-131.

Hirai, T. and M. Matsui. 2002. Feeding ecology of Bufo japonicus formosus from the montane region of Kyoto, Japan. Journal of Herpetology 36: 719-723. 
Hurlbert, S. H. 1978. The measurement of niche overlap and some relatives. Ecology 59: 67-77.

Hurtubia, J. 1973. Trophic diversity measurement in sympatric predatory species. Ecology 54: 885-890.

Hyatt, K. D. 1979. Feeding strategy. Pp. 71-119 in W. S. Hoar and D. J. Randall (eds.), Fish Physiology. Vol. VIII. New York. Academic Press.

IUCN, Conservation International and NatureServe. 2004. Global Amphibian Assessment. URL: http://www. globalamphibians.org. Captured on 13 December 2004.

King, R. P. 1986. Observations on Liza grandisquamis (Pisces: Mugilidae) in Bonny River, Nigeria. Hydrobiologie Tropical 19: 61-66.

Krebs, C. J. 1989. Ecological Methodology. New York. Harper Collins Publishers. 654 pp.

Lavilla, E. O., M. L. Ponssa, D. Baldo, N. Basso, A. Bosso, J. Céspedes, J. C. Chebez, J. Faivovich, L. Ferrari, R. Lajmanovich, J. A. Langone, P. Peltzer, C. Úbeda, M. Vaira, and F. Vera Candioti. 2000. Categorización de los anfibios de Argentina. Pp. 11-34 in E. O. Lavilla, E. Richard and G. J. Scrocchi (eds.), Categorización de los Anfibios y Reptiles de la República Argentina. San Miguel de Tucumán, Argentina. Asociación Herpetológica Argentina.

Levins, R. 1968. Evolution in Changing Environments. Princeton, New Jersey. Princeton University Press. 120 pp.

Lobos, G., P. Cattán and M. López. 1999. Antecedentes de la ecología trófica del sapo africano Xenopus laevis en la zona central de Chile. Boletín del Museo Nacional de Historia Natural (Chile) 48: 7-18.

Macchi, P. J., V. E. Cussac, M. F. Alonso, and M. A. Denegri. 1999. Predation relationships between introduced salmonids and the native fish fauna in lakes and reservoirs in northern Patagonia. Ecology of Freshwater Fish 8: 227-236.

Mazzucchelli, S. A. 1991. Parque Nacional Laguna Blanca. Relevamiento preliminar de las comunidades acuáticas. Buenos Aires, Argentina. Delegación Técnica Regional Patagónica, Administración de Parques Nacionales. 13 pp.

Ortubay, S., V. Cussac, M. Battini, J. Barriga, J. Aigo, M. Alonso, P. Macchi, M. Reissig, J. Yoshioka, and S. Fox. 2006. Is the decline of birds and amphibians in a steppe lake of northern Patagonia a consequence of limnological changes following fish introduction? Aquatic Conservation: Marine and Freshwater Ecosystems 16: 93-105.

Penczak, T., E. Kusto, D. Kryzanowska, M. Molinsky, and E. Suszyncka. 1984. Food consumption and energy transformation by fish population in two small lowland rivers in Poland. Hydrobiologie 108: 135-144.

Pielou, E. C. 1966. Species diversity and pattern diversity in the study of ecological succession. Journal of Theoretical Biology 10: 370-383.

Pincheira-Donoso, D. 2002. Nota sobre la alimentación de Pleurodema bufonina Bell, 1843 (Anura - Leptodactylidae). Gayana 66: 77-80.

Pinkas, L., M. S. Oliphant and Z. L. Iverson. 1971. Food habits of albacore, bluefin tuna, and bonito in California waters. California Department of Fish and Game, Fish Bulletin 152: 1-105.

Schoonbee, H. J., J. F. Prinsloo and J. G. Nxiweni. 1992. Observations on the feeding habits of larvae, juvenile and adult of the African clawed frog, Xenopus laevis, in impoundments in Transkei. Water SA 18: 227-236.

Secretaría de Ambiente y Desarrollo Sustentable. 2004. Res. 1030/04. Buenos Aires, Argentina. URL: http:// www.sernah.gov.ar. 